\title{
Pengaruh Pemberian Hormon Medroxy Progesterone Acetat terhadap Ketebalan Endometrium Rattus Norvegicus Betina Strain Wistar
}

\author{
Defi Yulita ${ }^{1}$, M. Biomed ${ }^{2}$ \\ ${ }^{1,2}$ STIKes Alifah Padang, Jln. Khatib Sulaiman No 52 B Padang \\ Correspondence email: defi_knu@yahoo.com
}

\begin{abstract}
Abstrak. Berdasarkan data BKKBN tahun 2013 ada 8.500.247 PUS yang merupakan peserta KB Baru, dengan paling banyak menggunakan Suntik 4.128 .115 (48,56\%). Tujuan Penelitian untuk mengetahui pengaruh pemberian hormon Medroxy Progesteron Acetat terhadap ketebalan endometrium Rattus Norvegicus Betina Strain Wistar. Rancangan penelitian ini The Post Test Only Control Goup Design, dengan Populasi tikus putih jenis Rattus Norvegicus Strain Wistar, Sampel diambil secara acak dari seluruh populasi yang memenuhi kriteria sampel sebagai berikut : Tikus berjenis kelamin betina, Berumur $12-14$ minggu, Memiliki berat badan $150-200$ gram. Berdasarkan perhitungan besar sample, maka diperoleh besar sampel/jumlah hewan coba $\mathrm{r}$ = 10 ekor tikus, dengan besar sampel secara keseluruhan untuk kedua kelompok baik perlakuan maupun kontrol adalah sebanyak 20 ekor tikus betina yang meliputi : Kelompok 1 berjumlah 10 ekor tikus yang tidak diberikan hormon Medroxy Progesterone Acetat sebagai kelompok control. Kelompok 2 berjumlah 10 ekor tikus yang diberikan hormon Medroxy Progesterone Acetat sebagai kelompok perlakuan. Hasil penelitian menunjukan rata - rata ketebalan endometrium pada kelompok (P1) Hormon Medroxy Progesterone Acetat adalah 493,17 $\mu \mathrm{m} \pm 114,96$ hasil ini lebih rendah dibandingkan dengan kelompok kontrol 1192,56 $\mu \mathrm{m} \pm 428,94$. Dari tabel uji ANOVA didapatkan nilai $\mathrm{P}<0,05$ yang berarti ada perbedaan yang sangat signifikan rata - rata ketebalan endometrium antara kelompok kontrol dengan kelompok perlakuan. Berdasarkan hasil uji Pos Hoc Test Bonfferoni, terlihat bahwa rata - rata ketebalan endometrium antara Kontrol dengan $\mathrm{P} 1$ menunjukan perbedaan yang signifikan $(\mathrm{P}<0,05)$. Analisa hasil penelitian dan pembahasan dapat disimpulkan bahwa : hormon Medroxy Progesteron Asetat berpengaruh terhadap ketebalan endometrium dan ada perbedaan gambaran histologi ketebalan endometrium akibat pemberian hormon Medroxy Progesteron Asetat dengan tanpa pemberian hormon
\end{abstract}

Kata Kunci: Hormon Medroxy Progesterone Acetat; Ketebalan Endometrium

Abstract. Based on the National Population and Family Planning Agency (BKKBN) data in 2013, there were 8,500,247 couples of childbearing age who were new KB (family planning) participants with the total number using injection was 4,128,115 (48.56\%). Research Objectives to find out The Effect of The Administration OF Medroxy Progesterone Acetate Hormone to Endometrial Thickness of The Female Rattus Norvegicus Wistar Strain. The design of this research is the post test only control group design by having white rats species Rattus Norvegicus Wistar Strain as the poplulation, the samples are taken randomly from all populations that met the following sample criteria: female rats, Aged 12-14 weeks, having body weight of 150 - 200 grams. Based on the calculation of the sample size, the sample size / number of animals $r=10$ rats was obtained, with a total sample size for both groups of treatment and control were 20 female rats which included: group 1 amounted to 10 rats that were not given Medroxy Progesterone Acetat hormones as a control group where group 2 amounted to 10 rats which given Medroxy Progesterone Acetat as a treatment group. The results showed the average endometrial thickness in the (P1) Medroxy Progesterone Acetate Hormone group was $493.17 \mu \mathrm{m} \pm 114.96$, this result was lower than the control group $1192.56 \mu \mathrm{m} \pm$ 428.94. From the ANOVA test table, the P value $<0.05$ means that there is a very significant difference in the average endometrial thickness between the control group and the treatment group. Based on the results of the Post Hoc Bonfferoni Test, it can be seen that the average endometrial thickness between Control and P1 showed a significant difference $(P<0.05)$. The analysis of the result and discussion of the research can be concluded that: the Medroxy Progesterone Acetate hormone affects the endometrial thickness, and there is a difference in the histological picture of endometrial thickness due to the administration of the Medroxy Progesterone Acetate hormone and without the administration of to the administration of the Medroxy Progesterone Acetate hormone.

Keywords: Endometrial Thickness; Medroxy Progesterone Acetate Hormone

\section{PENDAHULUAN}

Salah satu cara untuk menekan laju pertumbuhan penduduk adalah dengan menggunakan kontrasepsi. Saat ini banyak alternatif alat kontrasepsi yang bisa digunakan sesuai dengan kebutuhan. Ada beberapa alat kontrasepsi yang biasa digunakan diantaranya alat kontrasepsi sederhana (metode kalender, coitus interuptus, lendir servik, suhu basal, kondom, diafragma cap, spermisid). Metode kontrasepsi modern yang terdiri dari metode hormonal, Intra uterin Device (IUD) dan kontrasepsi mantap. jenis kontrasepsi efektif yang menjadi pilihan paling banyak adalah kontrasepsi suntik, karena relatif aman, efektif, sederhana dan murah. Kontrasepsi suntik dipakai lebih dari 90 negara dan telah digunakan selama lebih dari 20 tahun. Sampai saat ini akseptornya berjumlah kira - kira 5 juta jiwa. Di Indonesia kontrasepsi suntik ini diperkirakan 
dipergunakan oleh hampir setengah juta pasangan (Hartanto, 2004).

Berdasarkan data Badan Kependudukan dan Keluarga Berencana Nasional (BKKBN) tahun 2013 ada 8.500. 247 PUS yang merupakan peserta KB Baru dengan rincian sebagai berikut : penggunaan kontrasepsi Pil 2.261.480 (26,60\%), Suntik 4.128.115 (48,56\%), Implant 784.215 (9,23\%), IUD $658.632 \quad(7,75 \% 0$, Kondom 517.638 (6.09\%), MOW 128.793 (1,52\%), MOP $21.374(0,25 \%)$ (Pusat data dan informasi Kementerian Kesehatan RI, 2014)

Pencapaian peserta KB aktif semua metode kontrasepsi pada tahun 2015 di provinsi Sumatera Barat sebanyak 13.966 yang terdiri atas $5.701(47.4 \%)$ peserta suntik, peserta pil 3.170 (26.4\%), peserta AKDR (Alat Kontrasepsi Dalam Rahim) sebanyak 611 (5,1\%), peserta implant sebanyak 744 (6.2\%), peserta MOP (Medis Operasi Pria) dan peserta MOW (Medis Operasi Wanita) sebanyak 591 (5\%), peserta kondom sebanyak 1.203 (10\%). Pencapaian tertinggi pada suntikan (47.4\%) dan pencapaian terendah pada MOP dan MOW (5\%). (Profil Dinas Kesehatan Kota Sumatra Barat, 2016).

Pengguna kontrasepsi harus selektif dalam pemilihan kontrasepsi, karena tidak ada satupun metode kontrasepsi yang aman dan efektif bagi semua akseptor. Masing-masing kontrasepsi mempunyai kesesuaian dan kecocokan individual yang berbeda bagi setiap akseptor. Ketidak sesuaian dan ketidak cocokan bisa menimbulkan efek samping pada pemakai kontasepsi.

Efek samping kontrasepsi suntik Medroxy Progesterone Acetat antara lain gangguan perdarahan berupa amenorea, peningkatan berat badan, tekanan darah tinggi, jerawat, spotting / bercak darah. Sedangkan efek samping yang paling sering ditemukan adalah amenorea yang 50\% amenorrea terjadi setelah 1 tahun pemakaian pertama dan $72 \%$ terjadi setelah pemakaian selama 2 tahun (Hartanto, 2004).

Berdasarkan penelitian yang dilakukan oleh Manne tahun 1997 terhadap 100 orang akseptor yang menggunakan Medroxy Progesterone Acetat, Pada Akhir bulan ke-6 setelah pemakaian kontrasepsi hanya $10 \%$ yang mengalami haid teratur. Setelah selama 6 bulan di follow up kembali pengguna Medroxy Progesterone Acetat mengeluh mengalami amenorea.

Soetrisno (1993) pada penelitiannya menemukan: efek samping penggunaan Medroxy Progesterone Acetat mengalami amenorea $(50 \%)$, spoting $(20 \%)$, menoragia (15\%), mual dan sakit kepala (15\%). Insiden yang tinggi dari keluhan amenorrea diduga berhubungan dengan penipisan endometrium. Penelitian yang dilakukan Moghaddam (2006) menyatakan bahwa, proliferasi sel di pengaruhi hormonal dimana medroxy progesterone asetat akan menghambat proliferasi sel. Medroxy Progesterone Acetat merupakan regimen kontrasepsi progestin yang sering di gunakan dan bekerja jangka panjang. Medroxy Progesterone Acetat analog sintetik dari hormon progesteron alami yang dapat menekan sekresi gonadotropin hipofisis sehingga produksi Follicle Stimulating Hormone (FSH) dan Luteinizing Hormone (LH) juga terhambat.

Mekanisme kerja kontrasepsi suntik Medroxy Progesterone Acetat adalah menghambat sekresi gonadotropin sehingga akan mencegah terjadinya maturasi folikel primer di ovarium dan juga mencegah ovulasi serta menyebabkan penipisan endometrium (Mishell, 1996).

Berdasarkan fenomena diatas, peneliti tertarik untuk melakukan penelitian mengenai pengaruh pemberian hormon Medroxy Progesterone Acetat terhadap ketebalan endometrium Rattus Novergicus Betina Strain Wistar.

\section{METODE}

Rancangan penelitian The Post Test Only Control Goup Design (Arief, M. 2008). Penelitian dilaksanakan di Laboratorium Farmakologi Fakultas Farmasi Universitas Andalas Padang untuk pemeliharaan dan pemberian perlakuan terhadap tikus. Sedangkan untuk pemeriksaan histologi ketebalan endometrium dilakukan di Laboratorium Patologi Anatomi Fakultas Kedokteran Universitas Andalas Padang.

Populasi pada penelitian ini adalah tikus putih jenis Rattus norvegicus strain Wistar, Sampel diambil secara acak dari seluruh populasi yang memenuhi kriteria sampel untuk sampel penelitian sebagai berikut : Tikus berjenis kelamin betina, Berumur $12-14$ minggu, Memiliki berat badan 150 - 200 gram

Berdasarkan perhitungan besar sample dengan menggunakan rumus Abo Crombi, maka diperoleh besar sampel/jumlah hewan coba $r=10$ ekor tikus, dengan memperhitungkan kemungkinan terjadinya hewan coba yang mati/drop out sebesar 20\%, Dengan demikian besar sampel secara keseluruhan untuk kedua kelompok baik perlakuan maupun kontrol adalah sebanyak 20 ekor tikus betina yang meliputi : Kelompok 1 berjumlah 10 ekor tikus yang tidak diberikan hormon Medroxy Progesterone Acetat sebagai kelompok control. Kelompok 2 berjumlah 10 ekor tikus yang diberikan hormon Medroxy Progesterone Acetat sebagai kelompok perlakuan.

Tahap persiapan penelitian; Sebelum perlakuan dilakukan, tikus dipelihara selama \pm 2 minggu untuk penyesuaian dengan lingkungan dan diberikan pakan dan minum. Untuk menyamakan siklus estrus tikus, maka sebelum perlakuan diletakkan air kencing tikus jantan didalam kandang tikus betina yang berfungsi untuk merangsang estrus pada tikus betina (Hill, M. 2006). Kemudian tikus yang estrus dipindahkan ke tempat lain dan diberi label. Tikus dikelompokan menjadi 2 kelompok dengan rincian masing - masing kelompok 
Defi Yulita dan M. Biomed, Pengaruh Pemberian Hormon Medroxy Progesterone Acetat terhadap Ketebalan Endometrium Rattus Norvegicus Betina Strain Wistar

terdiri dari 10 ekor tikus. Kelompok 1 (Kontrol) tidak diberikan hormon Medroxy Progesteron Asetat sedangkan Kelompok 2 (P1) diberikan hormon Medroxy Progesterone Acetat.

Masing- masing kelompok tikus ditempatkan di kandang yang terpisah yang terbuat dari plastik dan diberi perlakukan selama 6 minggu efektif.

Tahap pelaksanaan penelitian : Hormon Medroxy Progesterone Acetat dengan dosis $0,05 \mathrm{ml}$ diberikan pada kelompok perlakuan dengan cara menginjeksikan secara Intra Muscular (IM) pada otot paha setiap 5 hari. Perlakuan diberikan selama 6 minggu. Pada hari ke 42 tikus dikorbankan dengan cara dilakukan dislokasi pada leher tikus, kemudian dibedah abdomennya dan diambil jaringan uterusnya. Jaringan uterus yang sudah diambil segera diletakkan pada wadah berisi formalin $10 \%$ dan langsung di pemeriksa ketebalan endometrium (Endardjo. 2008). Pemeriksaan histologis ketebalan endometrium menggunakan Mikroskop Olympus 4 TVO 5XC-3 Japan disertai dengan fasilitas pengukuran dalam micrometer (Fawcett, D. 2002).

Data yang diperoleh diolah dan di analisa dengan uji Anova dengan derajat kepercayaan 95\%, jika didapat hasil yang bermakna dari uji Anova dilanjutkan dengan uji statistik Post Hoc Test (Multiple Comparisons) jenis Bonferroni.

\section{HASIL DAN PEMBAHASAN}

Hasil penelitian terhadap 20 ekor tikus betina, umur 12-14 minggu dengan berat badan berkisar 150200 gram, yang dibagi 2 kelompok yaitu kelompok kontrol, P1. Kelompok kontrol adalah kelompok yang tidak diberi perlakuan, sementara kelompok P1 adalah kelompok yang diberi hormon Medroxy Progesterone Acetat dengan dosis 0,05 ml, Hasil yang diperoleh pada penelitian ini adalah sebagai berikut.

Tabel 1. Hasil Uji ANOVA terhadap Rata - Rata Ketebalan Endomterium Rattus Novergicus Betina Strain

Wistar.

\begin{tabular}{|l|c|c|}
\hline \multicolumn{1}{|c|}{ Kelompok } & $\begin{array}{c}\text { Ketebalan } \\
\text { Endometrium }(\boldsymbol{\mu m}) \\
\text { (Mean } \pm \text { SD) }\end{array}$ & P \\
\hline Kontrol & $1192,57 \pm 428,94$ & \multirow{2}{*}{$<0,000$} \\
\cline { 1 - 2 } $\begin{array}{l}\text { P1 (Medroxy } \\
\text { Progesterone Acetat) }\end{array}$ & $493,17 \pm 114,96$ & \\
\hline
\end{tabular}

Dari tabel uji ANOVA didapatkan nilai $\mathrm{P}<0,05$ yang berarti ada perbedaan yang sangat signifikan rata rata ketebalan endometrium antara kelompok kontrol dengan kelompok perlakuan. Dengan demikian dapat dilanjutkan dengan uji Pos Hoc Test Bonfferoni, untuk melihat lebih jelas perbedaan yang signifikan rata - rata ketebalan endometrium.
Tabel 2. Hasil Uji Pos Hoc Test Bonfferoni terhadap RataRata Ketebalan Endometrium Rattus Novergicus Betina Strain Wistar.

\begin{tabular}{|c|c|c|}
\hline Kelompok Kontrol & Kelompok Perlakuan & $\mathrm{P}$ \\
\hline Kontrol & $\begin{array}{c}\text { P1 (Medroxy } \\
\text { Progesterone Acetat) }\end{array}$ & 0,023 \\
\hline
\end{tabular}

Berdasarkan hasil uji Pos Hoc Test Bonfferoni, terlihat bahwa rata - rata ketebalan endometrium antara Kontrol dengan P1 menunjukan perbedaan yang signifikan $(\mathrm{P}<0,05)$.

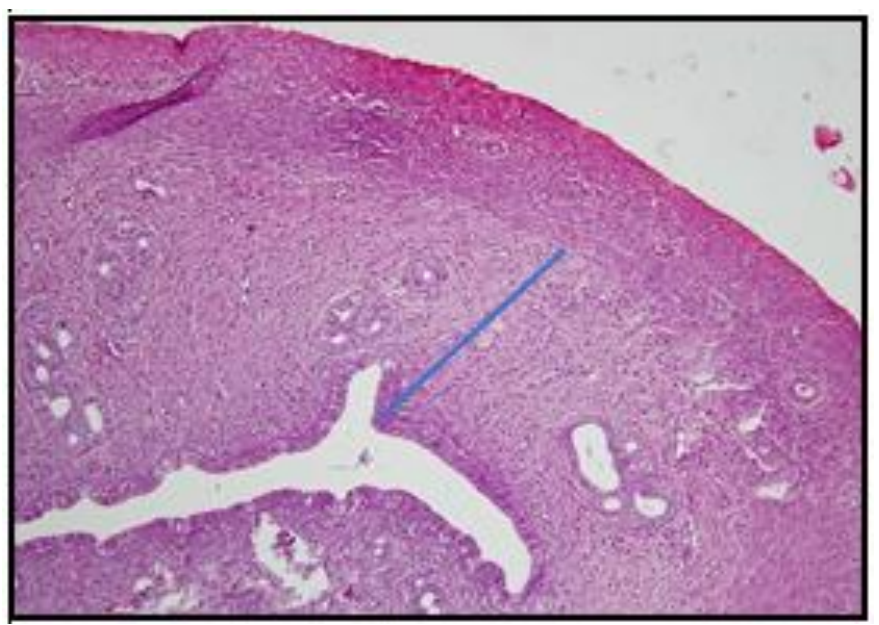

Kontrol (A)

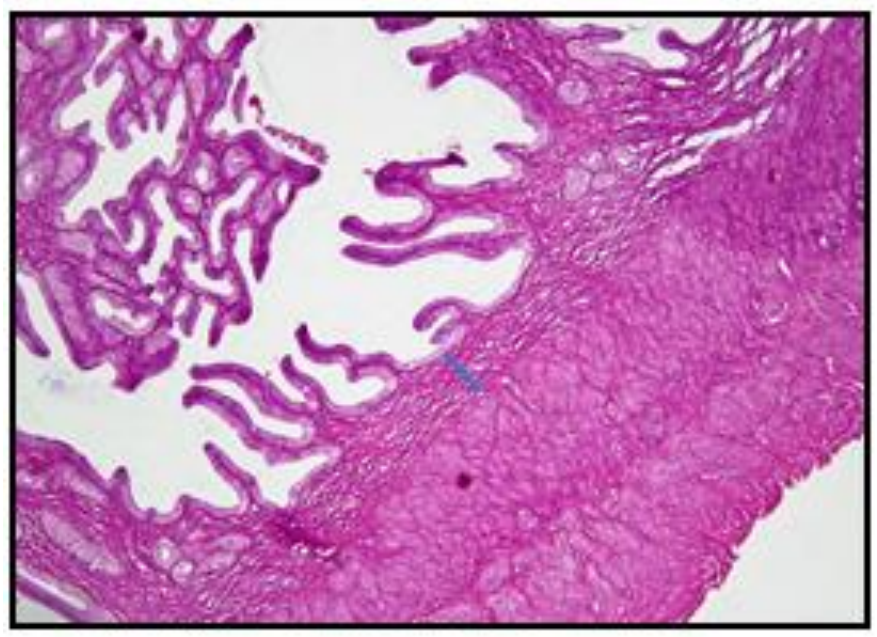

Medroxy Progesterone Acetat (P1)

Gambar 1. Perbandingan gambaran histologis ketebalan endometrium pada Rattus novergicus betina strain Wistar dengan pembesaran (10x10). Pada kelompok kontrol (A) terlihat stroma endometrium lebih longgar, permukaan endometrium lebih rata. Pada kelompok Medroxy

Progesterone Acetat (B) terlihat permukaan endometrium berbentuk tonjolan kecil seperti papila, stroma lebih padat dan sedikit.

Pada kelompok kontrol dapat dilihat secara mikroskopik permukaan endometrium lebih rata dengan epitel permukaan kolumnar. Kelenjar berkelompok, tubulus dilapisi epitel kuboid sampai kolumnar dengan stroma agak longgar. Pada kelompok Medroxy Progesteron Asetat dapat dilihat bahwa, permukaan 
endometrium berbentuk tonjolan kecil seperti papila, dimana kelenjar lebih rapat dan lebih dekat ke permukaan, kelenjar tidak mengalami hiperplasia, sebagian epitel permukaan kolumnar bentuk kuboid sampai kolumnar, stroma lebih padat dan sedikit, pembuluh darah sebagian hiperemis.

Hasil penelitian menunjukan rata - rata ketebalan endometrium pada kelompok (P1) Hormon Medroxy Progesterone Acetat adalah 493,17 $\mu \mathrm{m} \pm 114,96$ hasil ini lebih rendah dibandingkan dengan kelompok kontrol $1192,56 \mu \mathrm{m} \pm 428,94$. Hasil penelitian ini sama dengan penelitian Song Yu (1995) yang menyatakan bahwa progesteron mempengaruhi morfologis endometrium yang bervariasi dari penekanan pertumbuhan kelenjar endometrium melalui desidua stroma dan infiltrasi leukosit sampai pada atropi kelenjar dan nekrosis pada stroma.

Hal ini disebabkan karena Medroxy Progesterone Acetat mengandung hormon progesterone. Hormon ini akan mengurangi proliferasi yang dimiliki hormon estrogen baik terhadap epitel vagina maupun mengubah epitel uterus dari fase proliferasi ke fase sekresi. Hormon Medroxy Progesterone Acetat bekerja menghambat sekresi dari gonadotropin sehingga akan mencegah terjadinya maturasi dari folikel primer di ovarium dan juga mencegah ovulasi serta menyebabkan penipisan endometrium. Sebagai efek progestational tambahan, Medroxy Progesterone Acetat juga menyebabkan perubahan transformasi abortif sekretorik pada endometrium, yang lambat laun akan menjadi atropi (Mishell, 1996).

Progesteron menstimulasi suatu respon inflamasi didalam jaringan endometrium, sehingga jumlah total leukosit didalam endometrium meningkat nyata hingga sampai $40 \%$ stroma. Infiltrat inflamasi dari leukosit ini termasuk netrofril, eosinofil dan makrofag atau monosit ditarik oleh kemokin yang disintesis oleh sel - sel endometrium, leukosit menghasilkan bermacam macam molekul regulator termasuk sitokin, kemokin dan banyak enzim yang berkontribusi terhadap endometrium.

Degradasi enzimatik progresif dari endometrium pada akhirnya merusak sistim vaskuler venosa dan kapiler subpermukaan, menyebabkan perdarahan intersisial dari membran permukaan memungkinkan darah untuk keluar ke dalam rongga endometrium. Pada akhirnya, degenerasi meluas ke lapisan fungsional terdalam dimana ruptur arteriol - arteriol basal berkontribusi terhadap perdarahan. Deskuamasi dimulai pada fundus dan secara bertahap meluas ke arah ismus. Hasil akhirnya adalah endometrium menjadi tipis dan dangkal (Speroff, 1996).

Hal ini sama dengan hasil penelitian yang dilakukan oleh Fraser (1995) memperlihatkan bahwa penggunaan hormon steroid khususnya progesteron dapat meningkatkan radikal bebas. Adanya peningkatan radikal bebas di sebabkan oleh aktivasi sel - sel makrofag sebagai reaksi terhadap adanya nekrosis jaringan endometrium yang di rangsang oleh progesteron.

Secara mikroskopis terlihat jauh berbeda antara kelompok P1 dengan kelompok kontrol. Pada kelompok kontrol dapat dilihat permukaan endometrium lebih rata dengan epitel permukaan kolumnar. Kelenjar berkelompok, tubulus dilapisi epitel kuboid sampai kolumnar, terlihat stroma agak longgar. Jika di bandingkan dengan P1 dapat dilihat permukaan endometrium berbentuk tonjolan kecil seperti papilla dimana kelenjar lebih rapat dan lebih dekat ke permukaan, kelenjar tidak mengalami hiperplasia. Sebagian epitel permukaan kolumnar bentuk kuboid sampai kolumnar, pembuluh darah hiperemis dengan stroma lebih sedikit.

\section{SIMPULAN}

Berdasarkan analisa hasil penelitian dan pembahasan dapat disimpulkan bahwa: hormon Medroxy Progesteron Asetat berpengaruh terhadap ketebalan endometrium dan ada perbedaan gambaran histologi ketebalan endometrium akibat pemberian hormon Medroxy Progesteron Asetat dengan tanpa pemberian hormon

\section{DAFTAR PUSTAKA}

Arief, M. 2008. Pengantar Metodologi Penelitian untuk Ilmu Kesehatan. Solo: Sebelas Maret University Press.

Endardjo. 2008. Pedoman Penanganan Bahan Pemeriksaan untuk Histopatologi. Jakarta: Perhimpunan Dokter Spesialis Patologi Indonesia.

Fraser, J and Song, Y. 1995. Effects of Progesteron on Human Endometrium. Journal of Obstetri and Ginecology

Fawcett, D. 2002. Buku Ajar Histologi Edisi 12. Alih Bahasa; Jan Tambayong. Jakarta: EGC.

Hill, M. 2006. Estrous Cyle. The University of New South Wales. Sidney.

Hartanto, H. 2004. Keluarga Berencana dan Kontrasepsi. Jakarta: Pustaka Sinar harapan

Moghadam, H. 2006. The Hormone Replacement Therapy Drug Sibolone Acts Very Similar to Medroxy Progesterone Asetat in an Estrogene Responsive Endometrial Cancer Cell Line. Journal of molekuler endokrinologi.

Mishell. 1996. Pharmacokinetics of Depo medroxy Progesteron Acetat Contraception. Journal Reproduksi.

Manne, PA. 1997. Effectiveness of Cyclofem in the Treatment of Depo Medroxy Progesterone Asetat Induced Amenorrhea. The Journal of Contraception.

Pusat data dan informasi Kementerian Kesehatan RI, 2014 
Defi Yulita dan M. Biomed, Pengaruh Pemberian Hormon Medroxy Progesterone Acetat terhadap Ketebalan Endometrium Rattus Norvegicus Betina Strain Wistar

Profil Dinas Kesehatan Provinsi Sumatra Barat, 2016

Soetrisno. 1993. Pola Menstruasi dan Kelangsungan Pemakaian Cycloprovera dengan Depoprovera.

Song, Yu. 1995. Effects of Progesteron on Human Endometrium. Journal of Obstetri and Ginecology.

Speroff,L. and Kase NG. 1996. Long Methods of Contraseption Clinical Gynecologic endocrinology and fertility- $6^{\text {th }}$ ed Baltimore. 